\title{
OVERVIEW OF THE CRR 2009 RETIREMENT SURVEY
}

\author{
Alicia H. Munnell, Norma B. Coe, Kelly Haverstick, and Steven A. Sass
}

CRR WP 2010-15

Date Released: October 2010

Date Submitted: October 2010

\author{
Center for Retirement Research at Boston College \\ Hovey House \\ 140 Commonwealth Avenue \\ Chestnut Hill, MA 02467 \\ Tel: 617-552-1762 Fax: 617-552-0191 \\ http://crr.bc.edu
}

\begin{abstract}
Alicia H. Munnell is director of the Center for Retirement Research at Boston College (CRR). Norma B. Coe is associate director of research at the CRR. Kelly Haverstick is a research economist at the CRR. Steven A. Sass is program director of the Center for Financial Literacy at Boston College. The research reported here was performed pursuant to a grant from the U.S. Social Security Administration (SSA) funded as part of the Retirement Research Consortium (RRC). The opinions and conclusion expressed are solely those of the author and do not represent the opinions or policy of SSA, any agency of the federal government, the RRC, or Boston College.
\end{abstract}

(c) 2010, by Alicia H. Munnell, Norma B. Coe, Kelly Haverstick, and Steven A. Sass. All rights reserved. Short sections of text, not to exceed two paragraphs, may be quoted without explicit permission provided that full credit, including $(\subset)$ notice, is given to the source. 


\title{
About the Center for Retirement Research
}

The Center for Retirement Research at Boston College, part of a consortium that includes parallel centers at the University of Michigan and the National Bureau of Economic Research, was established in 1998 through a grant from the Social Security Administration. The Center's mission is to produce first-class research and forge a strong link between the academic community and decision makers in the public and private sectors around an issue of critical importance to the nation's future. To achieve this mission, the Center sponsors a wide variety of research projects, transmits new findings to a broad audience, trains new scholars, and broadens access to valuable data sources.

\section{Center for Retirement Research at Boston College}

\author{
Hovey House \\ 140 Commonwealth Avenue \\ Chestnut Hill, MA 02467 \\ phone: 617-552-1762 fax: 617-552-0191 \\ e-mail: crr@bc.edu \\ crr.bc.edu
}

Affiliated Institutions:

The Brookings Institution

Massachusetts Institute of Technology

Syracuse University

Urban Institute 


\begin{abstract}
In July and August 2009, the Center for Retirement Research at Boston College (CRR) conducted a survey to gauge three things: 1) how people were responding to the loss of their retirement assets due to the financial crisis; 2) who was responding by increasing their expected working life; and 3) how people were responding to realistic information about how long they would have to work or how much they would have to save in order to recoup their financial losses. This paper documents how the survey was conducted and contains all the relevant information to enable new users to start using this survey for their own research.

The paper is organized as follows. Section 1 discusses the survey methodology. Section 2 compares the demographic and basic characteristics between this survey and two nationally representative national surveys, the Survey of Income and Program Participation (SIPP) and the Current Population Survey (CPS). Section 3 discusses the weight adjustments needed to make the sample more representative of the U.S. population. Section 4 conducts a standard nonresponse analysis and Section 5 compares our findings to other surveys that also tried to gauge the reaction to the financial downturn. Section 6 concludes.
\end{abstract}




\section{Introduction}

In July and August 2009, the Center for Retirement Research at Boston College (CRR) conducted a survey to gauge three things: 1) how people were responding to the loss of their retirement assets due to the financial crisis; 2) who was responding by increasing their expected working life; and 3) how people were responding to realistic information about how long they would have to work or how much they would have to save in order to recoup their financial losses. This paper documents how the survey was conducted and contains all the relevant information to enable new users to start using this survey for their own research.

The paper is organized as follows. Section 1 discusses the survey methodology. Section 2 compares the demographic and basic characteristics between this survey and two nationally representative national surveys, the Survey of Income and Program Participation (SIPP) and the Current Population Survey (CPS). Section 3 discusses the weight adjustments needed to make the sample more representative of the U.S. population. Section 4 conducts a standard nonresponse analysis and Section 5 compares our findings to other surveys that also tried to gauge the reaction to the financial downturn. Section 6 concludes.

\section{Survey methodology}

KnowledgePanel

The CRR 2009 Retirement Survey was conducted on a subset of individuals from the KnowledgePanel $^{\circledR}$, maintained by Knowledge Networks (KN). KnowledgePanel is an online research panel constructed using probability sampling of the U.S. population. KnowledgePanel oversamples its random-digit dial (RDD) of African-American and Hispanic households using stratum telephone exchanges with high concentrations of minorities based on census data. Since the panel's start in 1999, several issues regarding the U.S. population have impacted the viability 
of using only RDD to select the sample. For example, the reduction in the number of landlines and the emergence of cell-phone-only households, the arrival of the National Do Not Call Registry, and the prevalence of caller-ID and answering machines warranted an adjustment to the RDD-only sampling method. Therefore, starting in April 2009, the KnowledgePanel includes an address-based sample (ABS) component to allow for recruitment of cell-phone-only households and to improve the representativeness of individuals in minority racial and ethnic groups, with lower education, and in lower income households. The ABS sample frame covers an estimated 98 percent of U.S. households. KN uses several techniques to merge the RDD and ABS samples to preserve the representativeness of the overall panel.

Extensive recruiting is conducted via mailings and telephone calls to households selected for the panel. Potential panelists are given either incentive points, which are redeemable for cash to participate if they have Internet access, or a laptop and Internet access if they do not have access. This allows for the survey to be a representative sample of the population, not just of the population that has Internet access.

For each survey, a random sample is drawn from the active panel members. Members selected for a survey are sent an e-mail that has a link to the questionnaire, which is open for varying lengths of time, depending on the design of the study. Automatic e-mail reminders are sent after three days, one week and, finally, two weeks. Because the general sampling rule is to assign no more than one survey per week, KN takes additional measures to ensure that samples are still representative when selected in weeks with surveys requiring a specific subsample.

\section{The CRR 2009 Retirement Survey Methodology}

On behalf of the CRR, KN fielded a survey using its KnowledgePanel on different aspects of retirement. The study's main focus was on: 
- retirement savings and money management before and after the economic downturn;

- plans for retirement before and after the economic downturn;

- relationships among retirement age, savings, and income.

The project consisted of two parts: a main survey followed by a short follow-up (re-ask) survey fielded to a subset of the survey respondents. The re-ask provided each respondent with estimates of the changes in the saving rate and the retirement age needed to counteract the reported loss in retirement savings. The survey questions elicited whether this financial knowledge altered respondents' reaction to the financial downturn.

A pretest of the main survey was fielded in late July 2009. The main survey was fielded approximately one week later. Because the main survey did not change from the pretest, the data are combined as part of the final dataset. The re-ask survey was fielded in early October 2009.

To be selected for the CRR 2009 Retirement Survey, a panel member must: be between 45 and 59; be in the labor force; and have retirement assets recorded in the KN Financial Services profile. KN preselected a sample of 2,941 households based on the ratio of retirement assets to income, as reported in the profile; 2,221 of these households initially responded to the participation request. However, the sample was trimmed further because employment status, income, or retirement assets might have changed since the profile information was given, so the inclusion criteria were re-evaluated in the field. In order to ensure the inclusion of enough observations with substantial retirement assets, quotas were instituted for six age and current retirement-assets-to-income ratio groups. The quotas and number of completed surveys are presented in Table 1. The final sample size is 1,317.

Finally, a re-ask portion of the survey questioned a subsample of participants about behavior after receiving financial advice. For this portion, 406 invitations were sent to 
respondents; 358 responded, a response rate of 88.2 percent. This subsample was selected based on the level of their retirement assets and the size of their financial loss.

Since the KnowledgePanel sample is not a pure equal probability sample, a base weight was calculated in order to make statistical adjustments based on the seven known selection criteria: gender; age; race; education; census region; household income; metropolitan area; Internet access. Additional adjustments for this study’s sampling design and non-response were made in study-specific, post-stratification weights. Section 3 discusses the weighting adjustments in further detail.

\section{Benchmarking the CRR 2009 Retirement Survey to the CPS and the SIPP}

The final sample consists of working, non-retired individuals aged 45-59 with ratios of retirement assets to current income between zero and six, exclusive. We can mirror the age and labor force status restrictions in the March 2009 CPS and the June 2009 SIPP in order to compare the CRR Retirement Survey (weight2) to other nationally representative surveys. However, the CPS and SIPP contain no information on retirement assets, and further adjustments to the weights are necessary to make the sample more representative of the general 45-59-yearold population who are labor-force participants. (This issue is discussed further in Section 3.) However, even without any further adjustments, the CRR 2009 Retirement Survey respondents look fairly similar to the 45-59-year-olds in the labor market from the March 2009 CPS and from the June 2009 SIPP, as is shown in Table 2.

The CRR 2009 Retirement Survey respondents are generally comparable to the nationally representative CPS and SIPP samples of labor-force participants aged 45 to 59 . While the weighted characteristics of the CRR 2009 Retirement Survey sample are slightly younger, more 
often living in the Midwest, more often living in a metropolitan area, and more likely to be never married/less likely to be divorced or separated, these differences are not statistically significant. ${ }^{1}$

Larger differences occur in the composition of race/ethnicity, education, and household income between the CRR 2009 Retirement Survey and the two nationally representative surveys, which is consistent with the extra screening in place for relatively high retirement assets. The CRR 2009 Retirement Survey sample includes a higher proportion of white, non-Hispanic individuals, is more highly educated, contains fewer individuals in households that have lowincome and more in households that have middle to high income. Generally, these differences are statistically significant. The next section will describe how adjustments can be made to better match these nationally representative values.

\section{Weight Adjustments to Represent the 45-59-Year-Old Working Population}

As described in previous sections, the survey respondents were benchmarked to be representative of the KnowledgePanel respondents who are 45-59 years old, labor-force participants, and have a distribution of assets to income similar to the quotas imposed. Table 3 shows the summary demographics for the CPS, the KnowledgePanel using the asset and income criteria, as well as the CRR 2009 Retirement Survey. Column (2) shows the weighted demographic characteristics of this selected subsample of the KnowledgePanel. The composition of the sample by age, gender, and region of the country are comparable to the CPS (column 1). However, race, education, and income differences are already apparent, explaining the aforementioned difference between the CRR 2009 Retirement Survey and the CPS. Column (3) presents the distribution of the panel members who responded to the survey, weighted to

\footnotetext{
${ }^{1}$ Within each of these categories, the only proportions that are statistically different at a 5-percent level between the CRR survey and the nationally representative surveys are two of the marital status variables: separated and never married.
} 
represent the KN-selected subsample (weight1). Column (4) presents the CRR 2009 Retirement Survey sample, also weighted to represent the KN-selected subsample (weight2). Using the respective weights, all respondents and the qualified respondents look very similar to the KnowledgePanel subsample.

However, further adjustments are needed if one wants to make the sample more representative of the aged 45-59-years-old, labor-force participants, as shown in the CPS. KN also created another weight, weight4, based on the demographic characteristics of the general population of 45-59-year-old labor-force participants. Using weight4, column (5) shows that the demographic characteristics of the qualified sample of 1,317 respondents are much closer to the CPS sample in the benchmark categories. However, using weight4 does not decrease the differences in other demographic characteristics not used as benchmarks, such as marital status. ${ }^{2}$

\section{Comparison of Qualified and Non-Qualified Respondents}

KN provided a file containing the data of the non-qualified respondents. This section describes the reasons for termination from the survey, documents the prevalence of termination for each reason, and compares the demographic characteristics of the non-qualified respondents to the qualified respondents. The termination process can be determined from the survey questionnaire. $^{3}$

Nine hundred four respondents were included in the non-qualified data set. The first potential termination occurs with the first screener question (scr1a), “Do you consider yourself

\footnotetext{
${ }^{2}$ As shown in Table 2, the CRR 2009 Retirement Survey has a greater weighted proportion of never-married individuals and a lower weighted proportion of separated individuals using weight2. Using weight4 does not make the estimates any closer for these marital status categories. This is also the case for the number of children under 18 living in the household of the respondents.

${ }^{3}$ Available at http://crr.bc.edu/images/stories/data\%20enclave/questionnaire_12_4_09.pdf.
} 
retired?” Respondents are terminated if they respond "Yes" or refuse to respond. Eighty three respondents were terminated at this stage. The second screener question (scr1b) asks, "Are you currently working for pay?” An additional 160 respondents were terminated at this stage for responding "No" or refusing to respond. The third screening question (scr2a) inquires about the level of retirement assets accumulated by the household, and the fourth (scr2b) is a follow-up question for those initially responding that they "Don’t know." Eight respondents were terminated for refusing to answer one of these two questions (four each). Using the midpoints of the categorical responses to questions concerning retirement wealth and income (ppincimp), the ratio of retirement wealth to income was calculated. One hundred fifty three respondents were terminated for having no retirement assets or a ratio value greater than or equal to six. The remaining unqualified respondents stated they were out of the labor force when asked for their best estimate of their target retirement age. ${ }^{4}$

Table 4 compares the demographic composition of the qualified versus unqualified respondents. The groups shown are the benchmark demographic and geographic distributions used in calculating the study-specific, post-stratification weights. ${ }^{5}$ The non-qualified respondents had approximately the same age distribution within the 45-59-year range, the same proportion living in a metropolitan statistical area, and region of the country. ${ }^{6}$

Significant differences occur for gender, ethnicity, education, income, and marital status. The non-qualified respondents had a greater proportion of women and non-Hispanic

\footnotetext{
${ }^{4}$ This variable is missing for 498 out of the remaining 500 respondents. Of the two with a valid expected retirement age, one respondent exited the survey without completing it while the other did not complete the survey by the end of the survey fielding period.

${ }^{5}$ Weights assigned to survey respondents were according to the most recent Current Population Survey based on the categories in Table 5, except marital status.

${ }^{6}$ A statistically significantly larger proportion of the non-qualified respondents lives in the Midwest. While the nonqualified group has smaller proportions living in the Northeast and South than the qualified respondents, these differences are not statistically significant at 10 percent.
} 
individuals. ${ }^{7}$ The non-qualified respondents had a lower proportion with low levels of education (less than high school or high school) and a higher proportion with some college. Non-qualified respondents were more likely to be in the lowest household income category (less than $\$ 25,000$ ) and less likely to be in the upper-middle income category (\$50,000 to less than $\$ 75,000)$.

Finally, the non-qualified respondents had a lower proportion of never-married respondents.

\section{Comparison of Responses from the CRR 2009 Retirement Survey to Responses Recorded}

\section{in Other Surveys}

Economic theory suggests workers will respond to a sharp decline in retirement wealth by working longer, saving more for retirement, and living on less in retirement. ${ }^{8}$ Previous surveys, however, suggest this might not be what workers have done (see Table 5). While these surveys report that many respondents intend to remain in the workforce longer, with little or no change in retirement saving, they often omit questions concerning retirement income changes.

\section{Work Longer}

Although conditional on the economy not improving significantly, the AARP Survey reports the highest proportion of individuals, almost two-thirds of workers aged 45 and older, likely to delay retirement and work longer. The Bank of America survey also finds that more than 40 percent of workers felt they faced more years in the workforce than expected a year ago. Evidence for a general increase in expected retirement ages for all workers comes from EBRI's

\footnotetext{
${ }^{7}$ Non-Hispanic individuals are categorized according to race. While the differences are not statistically significant for any of these race groups, the proportion of respondents who are Hispanic is statistically significantly lower in the group of non-qualified respondents.

${ }^{8}$ See Disney, Ratcliffe, and Smith (2010) for a review of research on the relationship between stock market fluctuations and labor market participation. For example, Gustman, Steinmeier, and Tabatabai (2009) estimate that the stock market decline will lead early baby boomers to delay retirement by an average of 1.5 months. Coile and Levine (2009) consider the impact of stock market changes and labor market fluctuations, finding that increase in retirement due to the high unemployment rate is considerably larger than the decrease attributable to the stock market crash.
} 
2009 Retirement Confidence Survey, which finds that a quarter of surveyed workers aged 25 and over had raised their expected retirement age. This increase is more than a 10-percentage-point jump from 2008, but is comparable to 2003 (after the bursting of the Internet bubble and a similar market decline) when 32 percent of surveyed workers reported that they had increased their expected retirement age. Finally, the Mercer Workplace Survey also finds no change from the previous year in the proportion of participants considering delaying retirement (31 percent in 2007 and 32 percent in 2008).

Because not all respondents in these surveys had significant retirement wealth, the response to the market decline could be significantly different for those households that have substantial retirement wealth losses. However, the CRR 2009 Retirement Survey reveals a consistent proportion (41 percent) of individuals delaying their retirement. In fact, the Prudential Survey, with the most similar sample and conducted at a similar time, also finds 41 percent postponing retirement.

Deciding to delay retirement appears to be the most frequent response to the market decline. The response, however, is potentially risky, particularly for older workers. In EBRI's 2009 Retirement Confidence Survey, 47 percent of current retirees report leaving the labor force earlier than expected. Most (90 percent) of these cite some negative reason for their early exit from the labor force, such as health problems or company downsizing. With the recent economic downturn, older workers may expect even greater difficulties in remaining in the workforce longer.

A more certain and immediate response to a large negative wealth shock would be to increase retirement saving. This involves sacrifice today - spending less on current consumption 
- not sacrifice tomorrow, through lower retirement income or having to delay retirement. However, workers seem not to have embraced this response.

\section{Saving More}

The majority of respondents in the 2008 Bank of America Retirement Savings Survey had not changed their retirement saving, management, or investment behavior during the three months leading up to the survey. EBRI‘s 2009 Retirement Confidence Survey reports very few workers changing their contributions to retirement savings plans. This is confirmed by reports from Vanguard and ICI, based on administrative data, both of which show contributions to retirement accounts have remained quite stable. Neither study reports any significant change in retirement plan withdrawals. By August 2009 most (67 percent) of the CRR 2009 Retirement Survey respondents also reported making no changes in the withdrawals and contributions to their retirement savings accounts.

Related to the level of saving is the allocation of retirement savings, EBRI's 2009 Retirement Confidence Survey also finds that workers are not reallocating how their retirement accounts are invested. This result is also confirmed by reports from Vanguard and ICI that used administrative data and found that around 15 percent of participants in defined contribution plans changed the asset allocation in their accounts in 2008 - much the same as in previous years. A more recent Vanguard study reports that a slightly lower 13 percent of participants traded in their retirement accounts in 2009. However, the CRR 2009 Retirement Survey finds a higher incidence (30 percent) of retirement asset reallocation. This difference may be due to the particular sample, as it includes only older workers and oversamples those who have large 
retirement wealth relative to current income. ${ }^{9}$ Supporting this notion is the Prudential Survey, which only included individuals who have at least $\$ 100,000$ in retirement savings and finds that almost half (48 percent) made some change to their investments.

\section{Conclusion}

The CRR 2009 Retirement Survey is a useful survey to assess how households responded to the financial crisis. The weighting scheme should be carefully selected based on the particular application, but the sample can be weighted to be representative to two distinct populations: the 45-59 year-old labor-force participants (weight4); and the 45-59 year-old labor-force participants with retirement-asset-to-income ratios between zero and six as prescribed by the quota (weight2). While the general findings are similar to other surveys about reactions to the downturn, this survey is unique in the breadth of information collected. It offers insights into what determines individuals' responses, including financial, employment, and psychological factors. Further, this survey includes two separate information experiments to see who changes their intended responses, and how they change. This survey provides numerous opportunities for future research.

\footnotetext{
${ }^{9}$ The data show a higher incidence of retirement asset reallocation in the oversampled groups of high retirement wealth to income ratios.
} 


\section{References}

AARP. 2008. "Retirement Security or Insecurity? The Experience of Workers Aged 45 and Older." Washington, DC. Available at:

http://assets.aarp.org/rgcenter/econ/retirement_survey_08.pdf.

Ameriks, John, Anna Madamba, and Stephen P. Utkus. 2009. "The Aftermath: Investor Attitudes in the Wake of the 2008-2009 Market Decline.” Volume 39. Valley Forge, PA: Vanguard Center for Retirement Research.

Bank of America. 2008. "Bank of America Survey Finds Despite Tightening Their Wallets, Americans Are Further from Achieving Their Retirement Goals Amidst Weakening Economy.” Available at: http://newsroom.bankofamerica.com/index.php?s=43\&item=8308.

Brightwork Partners LLC. 2008. "Mercer Workplace Survey: Summary for Employers.”

Coile, Courtney and Phillip B. Levine. 2009. “The Market Crash and Mass Layoffs: How the Current Economic Crisis May Affect Retirement.” Working Paper 15395. Cambridge, MA: National Bureau of Economic Research.

Disney, Richard, Anita Ratcliffe, and Sarah Smith. 2010. "Booms, Busts and Retirement Transitions.” Centre for Market and Public Organisation. University of Bristol. Available at http://www.netspar.nl/events/2010/pw/june/paperratcliffe.pdf.

Gustman, Alan L., Thomas L. Steinmeier, and Nahid Tabatabai. 2009. "What the Stock Market Decline Means for the Financial Security and Retirement Choices of the Near-Retirement Population.” Working Paper 15435. Cambridge, MA: National Bureau of Economic Research.

Helman, Ruth, Matthew Greenwald \& Associates, Craig Copeland, and Jack VanDerhei. 2009. "The 2009 Retirement Confidence Survey: Economy Drives Confidence to Record Lows; Many Looking to Work Longer.” Employee Benefit Research Institute Issue Brief No. 328. April.

Holden, Sarah, John Sabelhaus, and Brian Reid. 2010. "Enduring Confidence in the 401(k) System.” The Investment Company Institute.

Prudential. 2009. “Impact of the Market Crisis on Retirement Preparedness.” Prudential's Four Pillars of Retirement Series. September.

Utkus, Stephen P. and Jean A. Young. 2010. "Resilience in Volatile Markets: 401(k) Participant Behavior: September 2007-December 2009.” Vanguard research. 
Table 1: Quota and Respondents, by Age and Retirement Assets to Income Ratio

\begin{tabular}{|l|c|c|c|}
\hline Age Group & $\begin{array}{l}\text { Retirement assets to income } \\
\text { ratio }\end{array}$ & Sample size quota & $\begin{array}{l}\text { Number } \\
\text { Qualified }\end{array}$ \\
\hline Age 45-52 & $>0$ and $<0.4$ & 125 & 178 \\
\hline & $>0.4$ and $<1.6$ & 125 & 246 \\
\hline Age 53-59 & $>1.6$ and $<6$ & 250 & 260 \\
\hline & $>0$ and $<0.4$ & 125 & 143 \\
\hline & $>0.4$ and $<1.6$ & 125 & 230 \\
\hline Total & $>1.6$ and $<6$ & 250 & 260 \\
\hline
\end{tabular}


Table 2. Demographic Characteristics of Working Individuals, Aged 45-59, by Survey

\begin{tabular}{|c|c|c|c|c|c|}
\hline Characteristic & $\begin{array}{c}\text { March } 2009 \\
\text { CPS }\end{array}$ & $\begin{array}{l}\text { June } 2009 \\
\text { SIPP }\end{array}$ & $\begin{array}{c}\text { CRR } 2009 \\
\text { Retirement } \\
\text { Survey }\end{array}$ & $\begin{array}{c}\text { t-statistic } \\
\text { (CRR to } \\
\text { CPS) }\end{array}$ & $\begin{array}{c}\text { t-statistic } \\
\text { (CRR to } \\
\text { SIPP) }\end{array}$ \\
\hline Male & 0.519 & 0.520 & 0.525 & 0.26 & 0.23 \\
\hline \multicolumn{6}{|l|}{ Age Categories } \\
\hline $45-48$ & 0.300 & 0.302 & 0.318 & 0.88 & 0.76 \\
\hline 49-52 & 0.286 & 0.281 & 0.289 & 0.14 & 0.39 \\
\hline $53-55$ & 0.202 & 0.200 & 0.181 & -1.44 & -1.23 \\
\hline $56-59$ & 0.211 & 0.217 & 0.212 & -0.02 & -0.32 \\
\hline \multicolumn{6}{|l|}{ Race and ethnicity } \\
\hline White, non-Hispanic & 0.733 & 0.729 & 0.790 & 3.07 & 3.21 \\
\hline Black, non-Hispanic & 0.102 & 0.102 & 0.071 & -2.52 & -2.48 \\
\hline Other, non-Hispanic & 0.052 & 0.058 & 0.054 & 0.20 & -0.33 \\
\hline Hispanic & 0.105 & 0.111 & 0.080 & -2.02 & -2.43 \\
\hline Two or more races, non-Hispanic & 0.008 & ------ & 0.005 & -2.11 & -2.80 \\
\hline \multicolumn{6}{|l|}{ Education } \\
\hline Less than high school & 0.082 & 0.064 & 0.039 & -5.02 & -2.78 \\
\hline High school & 0.305 & 0.256 & 0.259 & -2.36 & 0.16 \\
\hline Some college & 0.284 & 0.354 & 0.287 & 0.15 & -3.49 \\
\hline Bachelor's degree or higher & 0.329 & 0.326 & 0.415 & 4.27 & 4.28 \\
\hline \multicolumn{6}{|l|}{ Region } \\
\hline Northeast & 0.192 & 0.188 & 0.191 & -0.04 & 0.22 \\
\hline Midwest & 0.230 & 0.229 & 0.250 & 1.08 & 1.13 \\
\hline South & 0.345 & 0.354 & 0.340 & -0.25 & -0.70 \\
\hline West & 0.233 & 0.229 & 0.219 & -0.83 & -0.59 \\
\hline \multicolumn{6}{|l|}{ Household income } \\
\hline Less than $\$ 25,000$ & 0.086 & 0.147 & 0.036 & -5.97 & -12.12 \\
\hline$\$ 25,000$ to $<\$ 50,000$ & 0.185 & 0.264 & 0.173 & -0.68 & -5.26 \\
\hline$\$ 50,000$ to $<\$ 75,000$ & 0.201 & 0.214 & 0.242 & 2.35 & 1.55 \\
\hline$\$ 75,000$ or more & 0.528 & 0.362 & 0.548 & 0.95 & 8.72 \\
\hline MSA & 0.812 & 0.835 & 0.840 & 1.77 & 0.32 \\
\hline \multicolumn{6}{|l|}{ Marital status } \\
\hline Married & 0.691 & 0.686 & 0.685 & -0.28 & -0.04 \\
\hline Widowed & 0.023 & 0.021 & 0.021 & -0.44 & 0.00 \\
\hline Divorced & 0.158 & 0.166 & 0.144 & -0.91 & -1.35 \\
\hline Separated & 0.025 & 0.020 & 0.010 & -3.04 & -2.00 \\
\hline Never married & 0.102 & 0.107 & 0.140 & 2.49 & 2.14 \\
\hline Observations & 33,408 & 8,105 & 1,317 & & \\
\hline
\end{tabular}

Note: All proportions are weighted. The CPS and SIPP samples are individuals aged 45 to 59, who are in the labor force. The MSA proportion is based on 27,441 CPS observations since it excludes observations where the MSA status is not identified. Weight2 is used for the CRR 2009 Retirement Survey.

Sources: Authors' calculations based on U.S. Bureau of Labor Statistics Current Population Study (CPS), 2009, CRR 2009 Retirement Survey, and the U.S. Census Bureau Survey of Income and Program Participation (SIPP), 2009. 
Table 3. Demographic Characteristics of Working Individuals, Aged 45-59, by Sample and Weight

\begin{tabular}{|c|c|c|c|c|c|}
\hline Characteristic & $\begin{array}{c}\text { March } \\
2009 \\
\text { CPS }\end{array}$ & $\begin{array}{c}\text { Knowledge } \\
\text { Panel with } \\
\text { asset/income } \\
\text { criteria }\end{array}$ & $\begin{array}{c}\text { All } \\
\text { respondents } \\
\text { (weight1) }\end{array}$ & $\begin{array}{c}\text { CRR } 2009 \\
\text { Retirement } \\
\text { Survey } \\
\text { (weight2) }\end{array}$ & $\begin{array}{c}\text { CRR } 2009 \\
\text { Retirement } \\
\text { Survey } \\
\text { (weight4) }\end{array}$ \\
\hline Male & 0.519 & 0.526 & 0.525 & 0.525 & 0.526 \\
\hline \multicolumn{6}{|l|}{ Age Categories } \\
\hline $45-48$ & 0.300 & 0.295 & 0.297 & 0.318 & 0.303 \\
\hline 49-52 & 0.286 & 0.281 & 0.275 & 0.289 & 0.285 \\
\hline 53-55 & 0.202 & 0.203 & 0.204 & 0.181 & 0.201 \\
\hline $56-59$ & 0.211 & 0.221 & 0.223 & 0.212 & 0.210 \\
\hline \multicolumn{6}{|l|}{ Race and ethnicity } \\
\hline White, non-Hispanic & 0.733 & 0.770 & 0.792 & 0.790 & 0.742 \\
\hline Black, non-Hispanic & 0.102 & 0.075 & 0.069 & 0.071 & 0.096 \\
\hline Other, non-Hispanic & 0.052 & 0.056 & 0.053 & 0.054 & 0.055 \\
\hline Hispanic & 0.105 & 0.092 & 0.079 & 0.080 & 0.100 \\
\hline Two+ races, non-Hispanic & 0.008 & 0.007 & 0.008 & 0.005 & 0.006 \\
\hline \multicolumn{6}{|l|}{ Education } \\
\hline Less than high school & 0.082 & 0.044 & 0.037 & 0.039 & 0.071 \\
\hline High school & 0.305 & 0.264 & 0.259 & 0.259 & 0.299 \\
\hline Some college & 0.284 & 0.292 & 0.299 & 0.287 & 0.292 \\
\hline Bachelor's or higher & 0.329 & 0.401 & 0.405 & 0.415 & 0.337 \\
\hline \multicolumn{6}{|l|}{ Region } \\
\hline Northeast & 0.192 & 0.198 & 0.191 & 0.191 & 0.187 \\
\hline Midwest & 0.230 & 0.240 & 0.242 & 0.250 & 0.232 \\
\hline South & 0.345 & 0.334 & 0.338 & 0.340 & 0.356 \\
\hline West & 0.233 & 0.229 & 0.228 & 0.219 & 0.225 \\
\hline \multicolumn{6}{|l|}{ Household income } \\
\hline Less than $\$ 25,000$ & 0.086 & 0.051 & 0.036 & 0.036 & 0.086 \\
\hline$\$ 25,000$ to $<\$ 50,000$ & 0.185 & 0.182 & 0.182 & 0.173 & 0.211 \\
\hline$\$ 50,000$ to $<\$ 75,000$ & 0.201 & 0.238 & 0.238 & 0.242 & 0.230 \\
\hline$\$ 75,000$ or more & 0.528 & 0.525 & 0.544 & 0.548 & 0.473 \\
\hline MSA & 0.812 & 0.847 & 0.846 & 0.840 & 0.830 \\
\hline Observations & 33,408 & ------ & 2,221 & 1,317 & 1,317 \\
\hline
\end{tabular}

Note: All proportions are weighted. The CPS sample includes individuals aged 45 to 59, who are labor-force participants. The MSA proportion is based on 27,441 CPS observations because it excludes observations where the MSA status is not identified.

Sources: Authors' calculations based on U.S. Bureau of Labor Statistics Current Population Study (CPS), 2009, and the CRR 2009 Retirement Survey. 
Table 4. Demographic Characteristics of Respondents, Aged 45-59, by Qualification Status

\begin{tabular}{|c|c|c|c|}
\hline Characteristic & $\begin{array}{c}\text { CRR } 2009 \\
\text { Retirement } \\
\text { Survey }\end{array}$ & $\begin{array}{l}\text { Non-Qualified } \\
\text { Respondents }\end{array}$ & $\begin{array}{c}\text { t-statistic } \\
\text { (Qualified to Non- } \\
\text { qualified) }\end{array}$ \\
\hline Male & 0.535 & 0.439 & -4.435 \\
\hline \multicolumn{4}{|l|}{ Age Categories } \\
\hline $45-48$ & 0.243 & 0.251 & 0.437 \\
\hline 49-52 & 0.276 & 0.281 & 0.237 \\
\hline $53-55$ & 0.217 & 0.200 & -0.962 \\
\hline $56-59$ & 0.263 & 0.268 & 0.221 \\
\hline \multicolumn{4}{|l|}{ Race and ethnicity } \\
\hline White, non-Hispanic & 0.847 & 0.861 & 0.913 \\
\hline Black, non-Hispanic & 0.051 & 0.061 & 1.013 \\
\hline Other, non-Hispanic & 0.033 & 0.025 & -0.982 \\
\hline Hispanic & 0.058 & 0.034 & -2.605 \\
\hline Two or more races, & 0.011 & 0.019 & 1.441 \\
\hline \multicolumn{4}{|l|}{ Education } \\
\hline Less than high school & 0.024 & 0.011 & -2.147 \\
\hline High school & 0.183 & 0.128 & -3.454 \\
\hline Some college & 0.307 & 0.360 & 2.604 \\
\hline Bachelor's degree or higher & 0.487 & 0.501 & 0.664 \\
\hline \multicolumn{4}{|l|}{ Region } \\
\hline Northeast & 0.185 & 0.170 & -0.900 \\
\hline Midwest & 0.279 & 0.320 & 2.083 \\
\hline South & 0.301 & 0.274 & -1.382 \\
\hline West & 0.235 & 0.236 & 0.054 \\
\hline \multicolumn{4}{|l|}{ Household income } \\
\hline Less than $\$ 25,000$ & 0.024 & 0.039 & 1.953 \\
\hline$\$ 25,000$ to $<\$ 50,000$ & 0.168 & 0.195 & 1.625 \\
\hline$\$ 50,000$ to $<\$ 75,000$ & 0.276 & 0.223 & -2.777 \\
\hline$\$ 75,000$ or more & 0.532 & 0.543 & 0.505 \\
\hline Metropolitan area & 0.856 & 0.846 & -0.618 \\
\hline Internet access & 0.123 & 0.073 & -3.825 \\
\hline \multicolumn{4}{|l|}{ Marital status } \\
\hline Married & 0.711 & 0.747 & 1.828 \\
\hline Widowed & 0.023 & 0.014 & -1.411 \\
\hline Divorced & 0.130 & 0.133 & 0.199 \\
\hline Separated & 0.008 & 0.013 & 1.126 \\
\hline Never married & 0.128 & 0.093 & -2.531 \\
\hline Observations & 1,317 & 904 & \\
\hline
\end{tabular}

Note: All proportions are unweighted.

Sources: Authors' calculations based on the CRR 2009 Retirement Survey and the CRR 2009 Retirement Survey Screened Out Respondents. 
Table 5. Overview of Related Surveys

\begin{tabular}{|c|c|c|c|}
\hline Survey Name & $\underline{\text { Sample }}$ & Field Dates & Relevance \\
\hline Mercer Workplace Survey & $\begin{array}{l}\text { Online survey of 2,204 workers who } \\
\text { participate in both employer's } 401(\mathrm{k}) \\
\text { plan and health benefits plan. }\end{array}$ & May 28-June 25, 2008 & $\begin{array}{l}\text { Measured expectations about the economy, } \\
\text { attitudes toward risk, and retirement } \\
\text { perspectives and investment behavior. }\end{array}$ \\
\hline $\begin{array}{l}\text { AARP Retirement Security } \\
\text { or Insecurity? }\end{array}$ & $\begin{array}{l}\text { Telephone survey of 1,628 employed } \\
\text { respondents } 45 \text { years and older }\end{array}$ & September 3-21, 2008 & $\begin{array}{l}\text { Measured how recent changes in the economy } \\
\text { have affected the financial security of older } \\
\text { workers. }\end{array}$ \\
\hline $\begin{array}{l}\text { ICI Survey: Retirement } \\
\text { Saving in the Wake of } \\
\text { Financial Market Volatility }\end{array}$ & Telephone survey of 3,000 households. & $\begin{array}{l}\text { October-December, } \\
2008\end{array}$ & $\begin{array}{l}\text { Measured retirement saving behavior and } \\
\text { asset allocation changes. }\end{array}$ \\
\hline $\begin{array}{l}2008 \text { Bank of America } \\
\text { Retirement Savings Survey }\end{array}$ & $\begin{array}{l}\text { 1,000 respondents to a RDD telephone } \\
\text { survey; } 750 \text { nationally representative } \\
\text { sample and } 250 \text { affluent ( } \$ 100,000-\$ 3 \\
\text { million of investable assets). }\end{array}$ & November 5-12, 2008 & $\begin{array}{l}\text { Measured behavioral response in retirement } \\
\text { asset allocation and saving. }\end{array}$ \\
\hline $\begin{array}{l}\text { EBRI‘s } 2009 \text { Retirement } \\
\text { Confidence Survey }\end{array}$ & $\begin{array}{l}\text { Telephone interviews of 1,257 } \\
\text { individuals aged } 25 \text { and above. }\end{array}$ & January 2009 & $\begin{array}{l}\text { Measures attitudes toward investment } \\
\text { companies and factors promoting confidence } \\
\text { in investment companies. }\end{array}$ \\
\hline $\begin{array}{l}\text { Prudential Survey: Impact } \\
\text { of the Market Crisis on } \\
\text { Retirement Preparedness }\end{array}$ & $\begin{array}{l}1,001 \text { individuals aged } 45-75 \text { who have } \\
\text { at least } \$ 100,000 \text { in retirement savings; } \\
\text { half were employed, half retired. }\end{array}$ & March-April 2009 & $\begin{array}{l}\text { Measured behavioral reactions, attitudes } \\
\text { toward risk, interest in new investment } \\
\text { products, attitudes toward advisors. }\end{array}$ \\
\hline $\begin{array}{l}\text { Vanguard: The Aftermath: } \\
\text { Investor Attitudes in the } \\
\text { Wake of the 2008-2009 } \\
\text { Declines }\end{array}$ & $\begin{array}{l}\text { Online respondents from the Harris } \\
\text { Interactive, Inc. panel. 3,012 } \\
\text { respondents between the ages of } 21 \text { and } \\
79 \text { with at least } \$ 5,000 \text { in long-term } \\
\text { savings and investments. }\end{array}$ & May 19-June 2, 2009 & $\begin{array}{l}\text { Measured changes in equity holdings since the } \\
\text { downturn, expectations of future returns, } \\
\text { feeling toward holding stocks. }\end{array}$ \\
\hline $\begin{array}{l}\text { Vanguard: Resilience in } \\
\text { volatile markets: } 401(\mathrm{k}) \\
\text { participant behavior }\end{array}$ & $\begin{array}{l}\text { Participant record data including } 3.2 \\
\text { million unique participants and } 3.4 \\
\text { million accounts in more than } 2,000 \\
\text { plans }\end{array}$ & $\begin{array}{l}\text { Covers the period of } \\
\text { October, } 2007 \text { to } \\
\text { December, } 2009\end{array}$ & $\begin{array}{l}\text { Summarizes DC plan participant behavior, } \\
\text { including investment, contribution, and } \\
\text { distribution behavior. }\end{array}$ \\
\hline
\end{tabular}




\section{RECENT WORKING PAPERS FROM THE CENTER FOR RETIREMENT RESEARCH AT BOSTON COLLEGE}

State Wage-Payment Laws, the Pension Protection Act of 2006 and 401(k) Saving Behavior Gary Engelhardt, October 2010

Asset Cycles and the Retirement Decisions of Older Workers Jan Ondrich, October 2010

Price Deflators, the Trust Fund Forecast, and Social Security Solvency Barry Bosworth, October 2010

The Impact of a DROP Program on the Age of Retirement and Employer Pension Costs Samson Alva, Norma B. Coe, and Anthony Webb, September 2010

Housing Consumption in Late Life: The Role of Income, Health Shocks, and Marital Shocks

Douglas A. Wolf and Janet M. Wilmoth, September 2010

Adjusting Social Security for Increasing Life Expectancy: Effects on Progressivity Courtney Monk, John A. Turner, and Natalia A. Zhivan, August 2010

Work and Retirement Patterns for the G.I. Generation, Silent Generation, and Early Boomers: Thirty Years of Change

Richard W. Johnson, Barbara A. Butrica, and Corina Mommaerts, July 2010

Spousal Health Shocks and the Timing of the Retirement Decision in the Face of ForwardLooking Financial Incentives

Courtney Harold Van Houtven and Norma B. Coe, June 2010

Incorporating Employee Heterogenity Into Default Rules for Retirement Plan Selection Gopi Shah Godi and Colleen Flaherty Manchester, May 2010

Accurately Measuring Health Over the Life Course

Fabian Lange and Doug McKee, May 2010

Getting to the Top of Mind: How Reminders Increase Saving Dean Karlan, Margaret McConnell, Sendhil Mullainathan, and Jonathan Zinman, April 2010

The Shrinking Tax Preference for Pension Savings: An Analysis of Income Tax Changes, 1985-2007

Gary Burtless and Eric Toder, March 2010

Social Security, Benefit Claiming and Labor Force Participation: A Quantitative General Equilibrium Approach

Selahattin Imrohoroğlu and Sagiri Kitao, March 2010

All working papers are available on the Center for Retirement Research website (http://crr.bc.edu) and can be requested by e-mail (crr@bc.edu) or phone (617-552-1762). 